\title{
Assessment in Social Work Education: A Bibliography
}

\author{
Robert Vernon \\ Mary Stanley
}

\section{1 e have attempted to provide the reader with a basic bibliography that examines multiple dimensions of assessment. While no bibliography is ever comprehensive, these $270+$ references may prove useful to the reader who wishes to further explore this literature.}

Airasian, Peter W. (2000). The theory and practice of portfolio and performance assessment. Journal of Teacher Education, v.51(5):398.

Akister, A., Bannon, H., \& Mullender-Lock, H. (2000). Poster presentations in social work education assessment: A case study. Innovationsin Education \& Teaching International 37(3) 229-233. (EJ613454)

Akister, J., \& Kim, C. (1998). Poster presentations: Finding alternatives to written assignments for assessing students. Journal on Excellence in College Teaching, 9(3) 19-31. (EJ603583)

Alter, C. \& Adkins, C. (2001). Improving the writing skills of social work students. Journal of Social Work Education, 37(3): 493-505.

Alverno College Faculty (1994). Student assessment-as-learning at Alverno College. Milwaukee, WI: Alverno College Institute.

Angelo, T.A. (1994). Classroom assessment: Involving faculty and students where it matters most. Assessment Update, 6(4), 1-2, 5,10.

Angelo, T.A., \& Cross, K.P. (1993). Classroom assessment techniques: A handbook for college teachers ( $2^{\text {nd }}$ ed.). San Francisco: Jossey-Bass, 1993.

Association of Baccalaureate Social Work Program Directors, Inc. (1999). Baccalaureateeducation assessment package. Available from John P. Rogers, Department of Social Work, Mount Mercy College, 133 Elmhurst Drive NE, Cedar Rapids, IA 52402. Also see: http:// www.rit.edu/ -beap/

Aviles, Christopher B. (2001). Implementing mastery learning in the social work classroom, pg. 27. (ERIC) (ED448401)

Aviles, Christopher B. (2001). Curriculum alignment: Matching what we teach and test versus teaching to the test, pg. 17. (ERIC) (ED448402)

Aviles, Christopher B. (2001). Grading with norm-referenced or criterion-referenced measurement: To curve or not to curve, that is the question, pg. 15. (ERIC) (ED446023)

Aviles, Christopher B. (2000). Teaching and testing for critical thinking with Bloom's Taxonomy of Educational Objectives, pg. 27. (ERIC) (ED446025)

Aviles, Christopher B. (1999). Understanding and testing for "critical thinking" with Bloom's Taxonomy of Educational Objectives, pg. 20. (ERIC)

Robert Vernon is Associate Professor and Mary Stanley is Social Work Librarian at the Indiana University School of Social Work, Indianapolis, IN 46202.

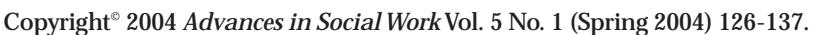

Indiana University School of Social Work. 
Bailey, S. \& Richards L. (2001). Challenges in evaluation: Assessing processes and outcomes in human service programs. Journal of Teaching in Marriageand Family, 1(4): 53-67.

Badger, L. \& MacNeil, G. (2002) Standardized clients in the classroom: A novel instructional technique for social work educators. Research on Social Work Practice, 12(3) 364-374.

Bakx, A., Sijtsma, K.,Van der Sanden, J., \& Taconis, R. (2002). Development and evaluation of a studentcentered multimedia self-assessment instrument for social-communicative competence. Instructional Science, 30(5), 335-359.

Bandura, A. (1977). Self-efficacy: Toward a unifying theory of behavior change. Psychological Review, 84(2), 191-215.

Bandura, A. (1995). Exercise of personal and collective efficacy in changing societies. In Bandura, A. (Ed.), Self-efficacy in changing societies, New York: Cambridge University Press.

Bandura, A. (1997). Self-efficacy: The exercise of control. New York: W.H. Freeman.

Bandura, A. Barbaranelli, C., Caprara, G.V., \& Pastorelli, C. (1996). Multifaceted impact of self-efficacy beliefs on academic functioning. Child Development, 67(3), 1206-1222. (EJ528236)

Bandura, A., (1982). Self-efficacy mechanism in human agency. American Psychologist, 37(2), 122-147.

Banta, T.W. (2003, March). Student outcomes assessment and social work education. Presented at the $49^{\text {th }}$ Annual Program Meeting of the Council on Social Work Education, Atlanta, GA.

Barab, S.A., \& Duffy, T.M. (2000). From practice fields to communities of practice. In D.H. Jonassen \& S.M. Lands (Eds.), Theoretical foundations of learningenvironments. Mahwah, NJ: Lawrence Erlbaum Associates.

Barise, A. (2000). The effectiveness of case-based instruction vs. the lecture-discussion method in multicultural social work. Dissertation Abstracts International Section A: Humanities \& Social Sciences, 61(6A), 2181.

Barnett, B.G., \& Lee, P. (1994). Assessment processes and outcomes: Building a folio. In L. Jackson \& R. Caffarella, (Ed.), Experiential learning: A new approach, 62 (Summer). CA: Jossey Bass. 55-62.

Barr, R., \& Tagg, J. (1995) From teaching to learning: A new paradigm for undergraduate education. Change, 27(6):12-26.

Barron, M. \& Sartori, N. (1994). Planning a portfolio: Medical record administration/Health information management. In M. Knight (Ed.), Portfolio assessment: An application of portfolio analysis. Lanham, MD: University Press of America. 9-19.

Barth, R., \& Gambrill, E. (1984). Learning to interview: The quality of training opportunities. TheClinical Supervisor, 2, 3-14.

Bartlett, T. (2003). What makes a teacher great? Chronicle of Higher Education, v.50(16):A8.

Becker, W. (in press). A critique of the quantitative research on teaching methods in tertiary education: What really works? In W.E. Becker \& M. Andrews (Eds.), The scholarship of teaching and learning in higher education: The contribution of research universities. Bloomington, IN: Indiana University Press.

Bereiter, C., \& Scardamalia, M. (1992). Cognition and curriculum. In P.W. Jackson (Ed.). Handbook of research on curriculum. New York: MacMillan Publishing.

Bernotavicz, F. (1994). A new paradigm for competency-based training. Journal of Continuing Social Work Education, 6, 3-9.

Biggerstaff, M. (2000). Development and validation of the Social Work Career Influence Questionnaire. Research on Social Work Practice, 10(1) 34-54.

Biley, F., \& Smith, K. (1999). Making sense of problem-based learning: The perceptions and experiences of undergraduate nursing students. Journal of Advanced Nursing, 30(5), 1205-1212.

Black P., \& Whelley J. (1999). The social work licensure exam: Examining the exam through the lens of CSWE curriculum policy. Aretê, 23(1): 66-76.

Bloom, M., Fischer, J., \& Orme, J. (1995). Evaluating practice: Guidelines for the accountable professional. Boston: Allyn \& Bacon.

Bogo, M., Regehr, C., Hughes, J., Power, R., \& Globerman, J. (2002). Evaluating a measure of student field performance in direct service: Testing reliability and validity of explicit criteria. Journal of Social Work Education, 38(3): 385-401. 
Brandon, J., \& Basanti, M. (1997). An introduction and evaluation of problem-based learning in health professions education. Family Community Health, 20(1), 1-15.

Bransford, J.D., Brown, A.L., Cocking, R.R., Donovan, M.S., \& Pellegrino, J.W. (Eds.). (2000). How people learn: Brain, mind, experienceand school (Expanded ed.). Committee on Developments in the Science of Learning and Committee on Learning Research and Educational Practice, Commission on Behavioral and Social Sciences and Education, National Research Council. Washington, D.C.: National Academy Press.

Bronstein, L., \& Kelly T. (2002) Qualitative methods for evaluating field education: Discovering how and what interns learn. Aretê, 25(2): 25-34.

Brufee, K. (1999). Collaborativelearning. Baltimore: Johns Hopkins University Press.

Burke, A., \&Julia, M. (2001). Outcomes based evaluation (OBE) training: Issues of technology transfer and relevance to social intervention. Journal of Social Work Research and Evaluation, 2(1): 19-28.

Irwin-DeVitis, L. (1996). Literacy portfolios: The myth and the reality. In M. Collins \& B. Moss, (Eds.), Literacy assessment for today's schools. VA: College Reading Association, 135-144.

Cahoon, B. (1998). New directions for adult and continuing education. San Francisco: Jossey-Bass.

Campbell, W., \& Smith, K. (1996). New paradigms for collegeteaching. Edina, MN: Interaction Book Co.

Cappell, C.L. (2002). Curriculum assessment: A case study in sociology. Teaching Sociology, v.30(4):467-494.

Carpio, B., Illesca, M., Ellis, P., Crooks, D., Droghetti, J., Tompkins, C., \& Noesgaard, C. (1999). Student and faculty learning styles in a Canadian and a Chilean self-directed, problem-based nursing program. Canadian Journal of Nursing Research, 31(3), 31-50.

Carter, R.T. (1993). Does race or racial identity attitudes influence the counseling process in black and white dyads? From J. Helms (Ed.), Black and whiteracial identity, pp. 145-175. Westport, CT: Praeger.

Cauble, A., \& Thurston, L. (2000). Effects of interactive multimedia training on knowledge, attitudes, and self-efficacy of social work students. Research on Social Work Practice, 10(4): 428-437.

Chambers, D.E., \& Spano, R. (1982). Integration of learning in field instruction. In B. Sheafor \& L. Jenkins. Quality field instruction in social work: Program development and maintenance, NY: Longman. 226-234.

Chapman, J.M. (2001). The portfolio: An instruction program assessment tool. ReferenceServices Review, v.29(4):294-301.

Chau, K.L. (1990). A model for teaching cross-cultural practice in social work. Journal of Social Work Education, 26, 124-133.

Chavkin, N., \& Brown, J. (2003). Preparing students for public child welfare: Evaluation issues and strategies. Journal of Human Behavior in the Social Environment. Special Issue: Charting theimpacts of university-child welfare collaboration, 7(1-2), 53-66.

Clare, B. (2003). Learning, practice and assessment: Signposting the portfolio. British Journal of Social Work, v.33(2):258-259.

Clark, S. (2003). The California collaboration: A competency-based child welfare curriculum project for master's social workers. Journal of Human Behavior in theSocial Environment. Special Issue: Charting the impacts of university-child welfare collaboration, 7(1-2) 135-157.

Clark, F., \& Horejsi, C. (1979). Mastering specific skills. In F. Clark \& M. Arkava. (Eds.), The pursuit of competencein social work. San Francisco: Jossey-Bass. 29-46.

Coe, J., \& Gandy, J. (1999) Perspectives from consumers (students) in a distance education program. Journal of Technology in Human Services. Special Issue: Computers and information technology in social work: Education, training, and practice, 16(2-3) 161-174.

Cole, B. (1991). Legal issues related to social work program admissions. Journal of Social Work Education, 27(1), 18-24.

Cole, B.S., \& Lewis, R.G. (1993). Gatekeeping through termination of unsuitable social work students: Legal issues and guidelines. Journal of Social Work Education, 29(2), 150-159.

Coleman, H., \& Collins, D. (2003). Problem-based learning and social work education. Common Ground Publishing: Victoria, Australia. (Also published simultaneously in the International Journal of Learning, (Volume 9). 
Conboy, A., Auerbach, C., Schnall, D., \& LaPorte H. (2000). MSW student satisfaction with using single system design computer software to evaluate social work practice. Research on Social Work Practice, 10(1):127-138.

Condon, W. (1994). Building bridges, closing gaps: Using portfolios to reconstruct the academic community. In L. Jackson \& R. Caffarella, (Eds.), Experiential learning: A new approach, 62(Summer). CA: Jossey Bass. 197-213.

Constable, R.T. (1977). A study of admissions policies in undergraduate education. Journal of Education for Social Work, 13(3), 19-246.

Cooper, J., \& Mueck, R. (1990). Student involvement in learning: Cooperative learning and college instruction. Journal on Excellence in College Teaching, 1, 68-76

Coulshed, V. (1993). Adult learning: Implications for teaching in social work education. British Journal of Social Work, 23, 1-13.

Council for Higher Education Accreditation. (2001, September) "Statement on Good Practices and Shared Responsibility in the Creation and Application of Specialized Accreditation Standards," Washington, D.C.: Author.

Council on Social Work Education, (2003). Handbook of Accreditation Standards and Procedures, $5^{\text {th }}$ edition. Alexandria, VA: Author.

Council on Social Work Education. (1994). Handbook of Accreditation Standards and Procedures, $4^{\text {th }}$ edition, Alexandria, VA: Author.

Cournoyer, B., \& Stanley, M. (2002). The social work portfolio: Planning, assessing and documenting lifelong learning in a dynamic profession. Menlo Park, CA: Wadsworth.

Cournoyer, B. (2001). Assessment of student learning in social work education the Indiana model. Advances in Social Work, 2(2): 128-151.

Cross, T.L., Bazron, B.J., Dennis, K.W., \& Isaacs, M.R. (1989). Toward a culturally competent system of care. Washington, D.C.: Georgetown University Child Development Center.

Cuming, H., \& Wilkins J. (2000). Involving service users in the assessment of students in professional practice. The Journal of Practice Teaching in Health and Social Work, 3(2):17-27.

Cunningham, L., \& Lester, S. (Eds). (1999). Developing the capable practitioner: Professional capability through higher education, London, Kogan Page.

Cuzzi, L.C., Holden, G., Chernack, P., Rutter, S., \& Rosenberg, G. (1997). Evaluating social work field instruction: Rotations versus year-long placements. Research on Social Work Practice, 7, 402-414.

Cuzzi, L.C., Holden, G., Rutter, S. Rosenberg, G., \& Chernack, P. (1996). A pilot study of fieldwork rotations vs. year long placements for social work students in a public hospital. Social Work in Health Care, 24, 73-91.

Daily, D.M. (1979) The validity of admissions predictions: A replication study and implications for the future. Journal of Education for Social Work, 15(2).

Daley, B.J. (1999). Novice to expert: An exploration of how professionals learn. Adult Education Quarterly, 49, 133-148.

Dalton, B. (2001). Distance education: A multidimensional evaluation. Journal of Technology in Human Services, 18(3-4) 101-115.

Dalton, B., \& Wright, L. (1999). Using community input for the curriculum review process. Journal of Social Work Education, 35(2) 275-288.

Doel, M. (2002). Learning, practice and assessment: Signposting the portfolio. London: Jessica-Kingsley.

Doel, M. (1999). No group is an island: Groupwork in a social work agency. Groupwork, v.22(3)50-69.

Donahue, B., \& Thyer, B.A. (1992). Should the GRE be used as an admissions requirement by schools of social work? Journal of Teaching in Social Work, 6(2), 33-40.

Dore, M.M., Epstein, B.N., \& Herrerias, C. (1992). Evaluating students micro practice field performance: Do universal learning objectives exist? Journal of Social Work Education, 28(3), 353-362.

Drisko, J. (2001). How clinical social workers evaluate practice. Smith CollegeStudiesin Social Work, 71(3): 419-439. 
Duehn, W.D., \& Mayadas, S. N. (1977). Entrance and exit requirements of professional social work education. Journal of Social Work Education, 13(2), 22-29.

Duffy, T., Dueber, B., \& Hawley, C. (1998). Effective collaborative learning. In C.J. Bonk \& K.S. King (Eds.), Electronic collaborators: Learning centered technologies for literacy, apprenticeship, and discourse Mahwah, NJ: Lawrence Erlbaum Associates Publishers.

Dunlap, K.M., Henley, C., Jr., \& Fraser, M.W. (1998). The relationship between admission criteria and academic performance in an MSW program. Journal of Social Work Education, 34(3), 455-462.

Dunlap, W.R. (1979). How effective are graduate social work admission criteria? Journal of Education for Social Work, 15, 96-102.

Elbow, P. (1994). Will the virtues of portfolios blind us to their potential dangers? In L. Black, D.A. Daiker, J. Sommers \& G. Stygall. (1994). New directions in portfolio assessment: Reflective practice, critical theory, and large-scale scoring (pp. 40-55). Portsmouth, NH: Boynton/Cook Publishers.

Ertmer, P.A., \& Newby, T.J. (1993) Behaviorisim, cognitivism, constructivism: Comparing critical features from an instructional design perspective. Performance Improvement Quarterly, 6(4), 50-72.

Ewell, P., \& Jones, D. (1996). Indicators of “Good Practice” in undergraduate education: A handbook for development and implementation: Boulder, Colorado: National Center for Higher Education Management Systems.

Fanney, V. (2003). Student self-assessment critical to outcomes-based curriculum. Social Work Education Reporter, 51(1), 21, 23.

Farr, Roger C. (1998). Portfolio and performance assessment: Helping students evaluate their progress as readers and writers. Fort Worth, TX: Harcourt Brace Publishers.

Finucane, S., Johnson, S., \& Prideaux, D. (1998). Problem-based learning: Its rationale and efficacy. Medical Journal of Australia, 168(4), 445-448.Fischer, K.M. (1994). Down the yellow chip road: Hypertext portfolios in Oz. In L. Jackson \& R. Caffarella, (Ed.), Experiential learning: A new approach, 62 (Summer).

Forrest, Aubrey. (1990). Time will tell: portfolio-assisted assessment of general education. Washington, D.C.: AAHE Assessment Forum.

Forster, M., \& Rehner, T. (1998) Part-time MSW distance education: A program evaluation. Computers in Human Services, 15(2-3) 9-21.

Fortune, A., \& Kaye, L. (2002) Learning opportunities in field practica: Identifying skills and activities associated with MSW students' self-evaluation of performance and satisfaction. Clinical Supervisor, 21(1) 5-28.

Frans, D.J. (1993). A scale for measuring social worker empowerment. Research on Social Work Practice, 3, 312-328.

Freddolino, P. (1998). Building on experience: Lessons from a distance education M.S.W. program. Computers in Human Services, 15(2-3) 39-50.

Gadzella, B., \& Masten, W. (1998). Critical thinking and learning processes for students in two major fields. Journal of Instructional Psychology, 25(4) 256-261.

Gambril, E. (2002). Evaluating the outcomes of social work practice: A pilot program. Journal of Social Work Education, 38(3), 355-360.

Gambril, E. (2001). Educational policy and accreditation standards: Do they work for clients? Journal of Social Work Education, 37(2), 226-239.

Gambril, E. (2001). Evaluating the quality of social work education: Options galore. Journal of Social Work Education, 37(3), 418-429

Gambril, E. (1990). Critical thinking in clinical practice. San Francisco: Jossey-Bass.

Garcia, J.A., \& Floyd, C. (2002). Addressing evaluative standards related to program assessment: How do we respond? Journal of Social Work Education, 38(3), 369-382.

Garcia, J.A., \& Floyd, C.E. (1999). Using single system design for student self-assessment: A method for enhancing practice and integrating curriculum. Journal of Social Work Education, 35(3), 451-461.

Gellis, Z. (2000). Social work online using the SUNY Learning Network. Focus on Teaching, 6(1), 4-5. Center for Excellence in Teaching and Learning, State University of New York at Albany. 
Gibbs, P. (1994). Gatekeeping issues in BSW programs. Aretê, 19(2), 15-27.

Gibbs, P. (1994). Screening mechanisms in BSW programs. Journal of Social Work Education, 30(1), 63-74.

Gijselaers, W. (1996). Connecting problem-based practices with educational theory. New Directions for Teaching and Learning, 68, 13-21.

Gingerich, W., \& Kaye, K. (1997). Assessment as learning: A model for educational innovation. In: Abilitybased social work education: Papers presented at the First Conference of the Mandel School of Applied Social Sciences' National Advisory Panel on Assessment in Social Work Education, September 20-22, 1996. Cleveland, OH: Mandel School of Applied Social Sciences, CaseWestern ReserveUniversity, 1997.

Gingerich, W., Kaye, K., \& Bailey, D. (1999). Assessing quality in social work education: Focus on diversity. Assessment and Evaluation in Higher Education, 24(2), 119-129.

GlenMaye, L., \& Oakes, M. (2002). Assessing suitability of MSW applicants through objective scoring of personal statements. Journal of Social Work Education, 38(1), 67-82.

Glisson, C.A., \& Hudson, W. (1981). Applied statistical misuse in educational research: An admissions criteria example. Journal of Education for Social Work, 18(2), 35-44.

Gokhale, A. (1995). Collaborative learning enhances critical thinking. [Online] Available: http://scholar.lib.vt.edu/ejournals/JTE/jte-v7n1/gokhale.jte-v7n1.html

Gopinath, C. (1999). Alternatives to instructor assessment of class participation. Education for Business, 51(10), 15-20.

Hackett, G., \& Betz, N. (1995). Self-efficacy and career choice and development. In J.E. Maddux. (Ed.). Self-efficacy, adaptation, and adjustment: Theory, research, and application, New York: Plenum Press.

Hadjistavropoulos H., Sagan, M., Bierlein, C., \& Lawson K. (2003). Development of a case management quality questionnaire. Care Management Journals, 4(1): 8-17.

Halpern, D. et al. (1994). The changing college classroom: New teaching and learning strategies for an increasingly complex world. San Francisco: Jossey Bass.

Hammel, J., Brasic Royen, C., Bagatell, N., Chandler, B., Jensen, G., Loveland, J., \& Stone, G. (1999). Student perspectives on problem-based learning in an Occupational Therapy curriculum: A multiyear qualitative evaluation. TheAmerican Journal of Occupational Therapy, 53, 199-206.

Helms, J. (1993). Black and whiteracial identity: Theory, research, and practice. Westport, CT: Praeger.

Helms, J. (1993). Measurement of black racial identity attitudes. In J.E. Helms (Ed.), Black and whiteracial identity: Theory, research, and practice (pp. 33-47). Westport, CT: Praeger.

Herman, L.P. (1999) Educational progressions: Electronic portfolios in a virtual classroom. T H E Journal (Technological Horizons in Education), v.26(11):86.

Holden, G., Anastas, J., \& Meenaghan, T. (2003). Determining attainment of the EPAS foundation program objectives: Evidence for the use of self-efficacy as an outcome. Journal of Social Work Education, $39,425-440$.

Holden, G., Meenaghan, T., Anastas, J., \& Metrey, G. (2002). Outcomes of social work education: The case for social work self-efficacy. Journal of Social Work Education, 38, 115-33.

Holden, G., Barker, K., Meenaghan, T., \& Rosenberg, G. (1999). Research self-efficacy: A new possibility for educational outcomes assessment. Journal of Social Work Education, 35(3), 463-476.

Holden, G., Cuzzi, L.C., Rutter, S., Chernack, P., Spitzer, W., \& Rosenberg, G. (1997). The Hospital Social Work Self-Efficacy Scale: A partial replication and extension. Health \& Social Work, 22, 256-263.

Holden, G., Cuzzi, L.C., Rutter, S., Chernack, P., \& Rosenberg, G. (1997). The Hospital Social Work SelfEfficacy Scale: A replication. Research on Social Work Practice, 7, 490-499.

Holden, G., Cuzzi, L.C., Rutter, S., Rosenberg, G., \& Chernack, P. (1996). The Hospital Social Work SelfEfficacy Scale: Initial development. Research on Social Work Practice, 6, 353-365.

Hollister, C., \& Kim, Y. (2001). Evaluating ITV-based MSW programs: A comparison of ITV and traditional graduates' perceptions of MSW program qualities. Journal of Technology in Human Services, 18(1-2) 89-100.

Honnebein, P. (1996) Seven goals for the design of constuctivist learning environments. In B. Wilson, (ed.). Constructivist learning environments: Case studies in instructional design. Englewood Cliffs, N.J.: Educational Technology Publications. 
House, J., \& Johnson, J. (2002). Predictive validity of the graduate record examination advanced psychology test for grade performance in graduate psychology courses. College Student Journal, 36, 32-37.

Howard, G., \& Dailey, P. (1979). Response shift bias: A source of contamination of self-report measures. Journal of Applied Psychology, 64, 144-150.

Howard, G., Daily, P., \& Gulanick, N. (1979). The feasibility of informed pretests in attenuating responseshift bias. Applied Psychological Measurement, 3, 481-494.

Howard, G., Ralph, K., Gulanick, N., Maxwell, S., Nance, D., \& Gerber, S. (1979). Internal invalidity in pretest-posttest self-report evaluations and a re-evaluation of retrospective pretests. Applied Psychological Measurement, 3, 1-23.

Howard, G., Schmeck, R., \& Bray, J. (1979). Internal validity in studies employing self-report instruments: A suggested remedy. Journal of Educational Measurement, 16, 129-135.

Huba, M.E., \& Freed, J.E. (2000). Learner-centered assessment on college campuses: Shifting the focus from teaching to learning. Boston: Allyn \& Bacon.

Huff, M., \& Edwards, S. (2001) Using technological tools to enhance learning in social work diversity courses. Journal of Technology in Human Services, 18(1-2) 51-64.

Huff, M., \& McNown-Johnson, M. (1998). Empowering students in a graduate-level social work course. Journal of Social Work Education, 34(3), 375-385.

Hull, G., Mather, J., Christopherson, P., \& Young, C. (1994). Quality assurance in social work education: A comparison of outcomeassessments across the continuum. Journal of Social Work Education, 30, 388-396.

Ingulsrud, John E. (2002). The assessment of cross-cultural experience: Measuring awareness through critical text analysis. International Journal of Intercultural Relations, v.26(5):473-491.

Ixer G. (1999). There's no such thing as reflection. British Journal of Social Work, 29(4): 513-527.

Jirovec R., Ramanathan, C., \& Alvarez A. (1998). Course evaluations: What are social work students telling us about teaching effectiveness. Journal of Social Work Education, 34(2): 229-236.

Johnston, B. (2004). Summative assessment of portfolios: An examination of different approaches to agreement over outcomes. Studies in Higher Education, v.29(3):395.

Jones, E. (2001). Portfolio assessment as a means of professional development. New Zealand Annual Review of Education Annual 2001, 10:187-203.

Jonnassen, D.H. (1991) Objectivism vs. constuctivism: Do we need a new philosophical paradigm. Educational Technology Research and Development, 39(3), 5-14.

Juniewicz, K. (2003). Student portfolios with a purpose. Clearing House, v.77(2):73.

Kane, M., Houston-Vega, M., Tan, P., \& Hawkins, W. (2002). Investigating factor structure of an instrument to measure social work students' preparedness for managed care environments. Social Work in Health Care, 35(4), 41-55.

Kanpol, B. (1998). Confession as strength: A necessary condition for critical pedagogy. Educational Foundations, v.12(2):63-75.

Karger, H.J ., \& Stoesz, D. (2003). The growth of social work education programs, 1985-1999: Its impact on economic and educational factors related to the profession of social work. Journal of Social Work Education, 39(2), 279-295.

Karoly, J.C. (1996). Using portfolios to assess students' academic strengths: A case study. Social Work in Education, v.18(3):178-186.

Kazi, M. (2000). Contemporary perspectives in the evaluation of practice. British Journal of Social Work, 30(6):755-768.

Kazi, M. (2003). Realist evaluation for practice. The British Journal of Social Work, 33(6): 803-818.

Katz, D. (1979). Laboratory training to enhance interviewing skills. In F. Clark \& M. Arkava, (Eds.). The pursuit of competence in social work. San Francisco: Jossey-Bass. 205-226.

King, A. (1993). From sage on the stage to guide on the side. College Teaching, 41(1), 30-35.

Knight, M. (Ed.). (1994). Portfolio assessment: An application of portfolio analysis. Lanham, MD: University Press of America. 
Knowles, A. (2001) Implementing web-based learning: Evaluation results from a mental health course. Journal of Technology in Human Services, 18(3-4) 171-187.

Knowles, M. (1980) The modern practice of adult education: From pedagogy to andragogy. Chicago: Association Press.

Knox, A.B. (1986). Helping adults learn. San Francisco: Jossey Bass.

Koerin, B., \& Miller, J. (1995). Gatekeeping policies: Terminating students for nonacademic reasons. Journal of Social Work Education, 31(2), 247-260.

Kolbo, J. \& Washington, E. (1999) Internet-Based instruction as an innovative approach to managing prerequisite curriculum content in a graduate social work program. Journal of Technology in Human Services. Special Issue: Computers and information technology in social work: Education, training, and practice, 16(2-3) 113-125.

Kramer, P., \& Stern, K. (1994). Portfolio assessment in occupational therapy. In M. Knight (Ed.), Portfolio assessment: An application of portfolio analysis. Lanham, MD: University Press of America. 121-134.

Kreuger, L. (1997) The end of social work. Journal of Social Work Education, 3(1), 19-27.

Krill, D. (1990) Practice wisdom: A guide for helping professionals. CA: Sage.

Kusnic, E., \& Finley, M.L. (1993). Student self-evaluation: An introduction and rationale. New Directions for Teaching and Learning, 56, 5-14).

Larson, L.M., \& Daniels, J.A. (1998). Review of the counseling self-efficacy literature. The Counseling Psychologist, 26, 179-218.

Latting, J.K. (1990). Identifying the "isms": Enabling social work students to confront their biases. Journal of Social Work Education, 26, 36-44.

Law, C. (2001). The state of art of social work evaluation and research in Hong Kong. Journal of Social Work Research and Evaluation, 2(1): 95-102.

Le-Doux, C., \& Montalvo, F.F. (1999). Multicultural content in social work graduate programs: A national survey. Journal of Multicultural Social Work, 7(1/2), 37-55.

Lettus, M.K. (2001). The clinical portfolio as an assessment tool. Nursing Administration Quarterly, v.24(2):74.

Lewis L.H., \& Williams C.J. (1994). Experiential learning: Past and present. In L. Jackson \& R. Caffarella, (Ed.), Experiential learning: A new approach, 62(Summer). CA: Jossey Bass. 5-16.

Ligon, J., DeWeaver, K., \& Greene, K. (2002). Outcome studies and reaccreditation: Issues and recommendations. Aretê, 26(1): 61-70.

Ligon, J., Markward, M., \& Yegidis, B. (1999). Comparing student evaluations of distance learning and standard classroom courses in graduate social work education. Journal of Teaching in Social Work, 19(1/2): 21-29.

Lohman, M ., \& Finkelstein, M. (2000). Designing groups in problem-based learning to promote problemsolving skill and self-directedness. Instructional Science, 28(4), 291-307.

Lucal, Betsy. (2003). Faculty Assessment and the scholarship of teaching and learning: Knowledge available/knowledge needed. Teaching Sociology, v.31(2):146-161.

Lum, D. (1999). Culturally competent practice: A framework for growth and action. Pacific Grove, CA: Brooks/Cole.

Maclsaac, D., \& Jackson, L. (1994). Assessment processes and outcomes: Portfolio construction. In L. Jackson \& R. Caffarella, R., (Ed.), Experiential learning: A new approach, 62(Summer). CA: Jossey Bass. 63-72.

Macy, J.A., Rooney, R.H., Hollister, C.D., \& Freddolino, P.P. (2001). Evaluation of distance education programs in social work. Journal of Technology in Human Services, 18(3/4), 63-84.

Magen, R.H., \& Emerman, J. (2000). Should convicted felons be denied admission to a social work education program? Yes! Journal of Social Work Education, 36(3), 401-408.

Manoleas, P. (1994). An outcome approach to assessing the cultural competence of MSW students. Journal of Multicultural Social Work, 3(1), 43-57. 
Margetson, D. (1993). Understanding problem-based learning. Educational Philosophy Theory, 25(40), 40-57.

Mathews, Jay. (2004). Portfolio assessment: Carrying less weight in the era of standards-based accountability. Education Next Summer 2004, 4(3):72-76.

McClelland, R.W., Rindfleisch, N., \& Bean, G.J., Jr. (1991). Rater adherence to evaluative criteria used in BSSW admissions. Aretê, 16(2), 10-18.

McGrath, D. (2003). Rubrics, portfolios, and tests, oh my! Assessing understanding in project-based learning. Learning \& Leading with Technology, 30(3):42-46.

McPhatter, A. (1997). Cultural competence in child welfare: What is it? How do we achieve it? What happens without it? Child Welfare, 76, 255-278.

Miah, M., Mizanur R., \& Newcomb, P.R. (1995). Outcome measures in social work education in the United States: A national survey. International Social Work, (38), 79-86.

Miholic, V. (2001). Rethinking portfolio applications and assessment. Journal of College Reading and Learning, 32(1):5-14.

Miller, J., \& Koerin, B. (1998). Can we assess suitability at admission? A review of MSW application procedures. Journal of Social Work Education, 34(3), 437-453.

Milner, M., McNeil, J., \& King, S. (1984). The GRE: A question of validity in predicting performance in professional schools of social work. Educational and Psychological Measurement, 44, 945-950.

Minter, D. (2002). Composition, pedagogy \& the scholarship of teaching. Portsmouth, NH: Boynton/Cook Publishers.

Montgomery, L.A. (2003). Digital portfolios in teacher education: Blending professional standards, assessment, technology and reflective practice. Computers-in-the-Schools, v.20(1/2):171-186.

Moore, L., \& Urwin, C. (1991). Gatekeeping: A model for screening baccalaureate students for field education. Journal of Social Work Education, 27(1), 8-17.

Moore, L., Dietz, T., \&Jenkins, D. (1998). Issues in gatekeeping. The Journal of Baccalaureate Social Work, 4(1), 37-50.

Morrow, D.F. (2000). Gatekeeping for small baccalaureate social work programs. The Journal of Baccalaureate Social Work, 5(2), 65-80.

Mosteller, F. (1989). The “Muddiest Point in the Lecture” as a feedback device. On Teaching and Learning: The Journal of the Harvard-Danforth Center, 3, 10-21.

Moxley, D.P., Najor-Durack, A., \& Dumbrigue, C.Y. (2000). Seven strategies for facilitating access of nontraditional students to graduate education in social work. Social Work Education, 19, 335-348.

Multon, K.D., Brown, S.D., \& Lent, R.W. (1991). Relation of self-efficacy beliefs to academic outcomes: A meta-analytic investigation, Journal of Counseling Psychology, 38, 30-38.

Neuman, K. (2002) From practice evaluation to agency evaluation: Demonstrating outcomes to the United Way. Social Work in Mental Health, 1(2): 1-14.

Noble, J., J r., \& Stretch, J. (2002) Grade-induced beliefs about undergraduate generalist social work practice competency. Evaluation Review, 26(2), 213-236.

Norman, G., \& Schmidt, H. (1992). The psychological basis of problem-based learning: A review of the evidence. Academic Medicine, 67, 557-565.

Nunnally, J., \& Bernstein, I.H. (1994). Psychometric theory ( $3^{\text {rd }}$ Ed.). New York: McGraw-Hill.

Nurius, P., \& Hudson, W. (1999). Human Services, Practice, Evaluation and Computers. Pacific Grove, CA: Brooks/Cole.

O’Hare, T., \& Collins, P. (1997). Development and validation of a scale for measuring social work practice skills. Research on Social Work Practice, 7(2), 228-238.

O'Hare, T., \& Collins, P. (1998). Validation of the Practice Skills Inventory with experienced clinical social workers. Research on Social Work Practice, 8(5), 552- 564.

O'Neal, Gwenelle, S. (1996). Enhancing undergraduate student participation through active learning. Journal of Teaching in Social Work, 13(1/2), 141-156. 
Ouellette, P. (1999). Moving toward technology-supported instruction in human service practice: The “Virtual Classroom." Journal of Technology and Human Services, 16(2/3), 97-111.

Palomba, C.A., \& Banta, T.W. (1999). Assessment essentials: Planning, implementing, and improving assessment in higher education. San Francisco: Jossey-Bass.

Patchner, M., Petracchi, H., \& Wise, S. (1998). Outcomes of ITV and face-to-face instruction in a social work research methods course. Computers in Human Services, 15(2-3) 23-38.

Petracchi, H., \& Patchner, M. (2001). A comparison of live instruction and interactive televised teaching: A 2-year assessment of teaching an MSW research methods course. Research on Social Work Practice, 11(1): 108-117.

Petracchi, H., \& Patchner, M. (2000). Social work students and their learning environment: A comparison of interactive television. Journal of Social Work Education, 36(2): 335-347.

Petracchi, H. (1998). The combined use of video and one way broadcast technology to deliver baccalaureate education: A comparative assessment of student learning in a school of social work. The Journal of Baccalaureate Social Work, 4(1): 51-59.

Paulson, L., \& Paulson, P. (1990, August). How do portfolios measure up? Paper presented at the Annual Meeting of the Northwest Evaluation Association, Union, WA. (ERIC Document Reproduction Service No. ED 324 329).

Paulson, P.R., \& Paulson, F.L. (1994). A different understanding. In L. Jackson \& R. Caffarella, (Eds.), Experiential learning: A new approach, 62(Summer). CA: Jossey Bass. 278-292.

Pelech, W., Stalker, C.A., Regehr, C., \&Jacobs, M. (1999). Making the grade: The quest for validity in admissions decisions. Journal of Social Work Education, 35(2), 215-226.

Pfouts, J.H., \& Henley, H.C. (1977). Admissions roulette: Predictive factors for success in practice. Journal of Education for Social Work, 13, 56-63.

Pike, C. (1998). A validation study of an instrument designed to measure teaching effectiveness. Journal of Social Work Education, 34(2): 261-271.

Pithouse, A., \& Scourfield, J. (2002). Ready for practice? The DipSW in Wales: Views from the workplace on social work training. Journal of Social Work, 2(1), 7-27.

The Professional Counselor; Portfolio, Competencies, Performance Guidelines, and Assessment, 3rd ed. (2004). SciTech Book News, 28(1):2.

Proctor, E., Rosen, A., \& Rhee, C. (2002). Outcomes in social work practice. Journal of Social Work Research and Evaluation, 3(2): 109-125.

Ponterotto, J.G., \& Alexander, C.M. (1996). Assessing the multicultural competence of counselors and clinicians. In L. Suzuki, P. Meller \&J. Ponterotto, (Eds.), Handbook of multicultural assessment, (pp. 651672). San Francisco: Jossey-Bass Publishers.

Poole, D.L. (1998). Politically correct or culturally competent? Health and Social Work, 23, 163-166.

Pray, J. (2001). Enhancing critical thinking and professionalism through use of the discussion forum in social work practice courses. Journal of Technology in Human Services, 18(1-2) 65-75.

Ragg, M.D., \& Mertlich, G. (1999, March). Toward measuring practice skill outcomes: Three measures of practice skill. Paper presented at the Annual Planning Meeting of the Council of Social Work Education, San Francisco, CA.

Regehr, C., Regehr, G., Leeson, J., \& Fusco, J. (2002) Setting priorities for learning in the field practicum: A comparative study of student and field instructors. Journal of Social Work Education, 38(1) 55-65.

Rhodes, R., Ward, J., Ligon, J., \& Priddy, W. (1999). Fighting for field: Seven threats to an important component of social work education. The Journal of Baccalaureate Social Work, 5(1), 15-25.

Rich, S. (1994). Test me, Test me not: The portfolio alternative for developmental writers. In M. Knight (Ed.), Portfolio assessment: An application of portfolio analysis. Lanham, MD: University Press of America. 47-63.

Richardson, T.Q., \& Molinaro, K.L. (1996). White counselor self-awareness: A prerequisite for developing multicultural competence. Journal of Counseling and Development, 74, 238-242.

Risler, E. (1999). Student practice portfolios: Integrating diversity and learning in the field experience. Aretê, 23(1), 89-96. 
Ronnau, J.P. (1994). Teaching cultural competence: Practical ideas for social work educators. Journal of Multicultural Social Work, 3(1), 29-42.

Saleebey, D. (1997) The strengths perspective in social work practice. White Plains, N.Y: Longman.

Sampson, C., \& Boyer, P.G. (2001). GRE scores as predictors of minority students' success in graduate study: An argument for change. College Student Journal, 35, 271-280.

Scannapieco, M., \& Connell-Corrick, K. (2003) Do collaborations with schools of social work make a difference for the field of child welfare? Practice, retention and curriculum. Journal of Human Behavior in the Social Environment. Special Issue: Charting theimpacts of university-child welfarecollaboration, 7(1-2) 35-51.

Scannapieco, M., Bolen, R., \& Connell, K. (2000). Professional social work education in child welfare: Assessing practice knowledge and skills. Professional Development, 3(1): 44-56.

Schatz, M., \& Simon, S. (1999). The portfolio approach for generalist social work practice: A successful tool for students in field education. Journal of BaccalaureateSocial Work, 5(1), p. 99-107.

Schon, D. (1987). Educating the reflective practitioner. San Francisco: Jossey-Bass.

Schon, D. (1983). The reflective practitioner: How professionals think in action. NY: Basic Books.

Schumann, C. (2000). Research into the role of the practice assessor. The Journal of Practice Teaching in Health and Social Work, v.3(2):5-16.

Scriven, M. (1999). The fine line between evaluation and explanation. Research on Social Work Practice, 9(4): 521-524.

Scott, N., \& Zeiger, S. (2000). Should convicted felons be denied admission to a social work education program? No! Journal of Social Work Education, 36(3), 409-413.

Secret, M., Jordan, A., \& Ford, J. (1999). Empowerment evaluation as a social work strategy. Health and Social Work, 24(2): 120-127.

Shadday, T. (1999). Problem-based learning: Preparing learners for the $21^{\text {st }}$ Century. Journal of Health Education, 30(6) 369-371.

Shepard, G., \&Wahle, L.P. (1981). A competency-based approach to social work education: Does it work? Journal of Education for Social Work, 17(3), 75-82.

Shor, R., \& Sykes, I. (2002) Introducing Structured Dialogue with people with mental illness into the training of social work students. Psychiatric Rehabilitation Journal, 26(1), 63-69.

Sidell, N.L. (2003). The course portfolio: A valuable teaching tool. Journal of Teaching in Social Work, v.23(3/4):91-106.

Simon, S., \& Schatz, M. (1998). The portfolio approach for BSW generalist social work students. TheNew Social Worker 5(1), 12-15.

Slaught, E.F., \& Raskin, M.S. (1995). Assessing BSW programs: An outcome-driven approach. Journal of Social Work Education, 31(1), 17-27.

Slavin, R.E. (1996) Research on cooperative learning and achievement: What we know, what we need to know. Contemporary Educational Psychology, 21, 43-69.

Slonim-Nevo, V., \& Ziv, E. (1998) Training social workers to evaluate practice. International Social Work, 41(4): 431-442.

Snavely, L.L. (2003). Research portfolio use in undergraduate honors education: Assessment tool and model for future work. Journal of Academic Librarianship, v.29(5):298.

Spicuzza, F. (2000). Portfolio assessment: Meeting the challenge of a self study. The Journal of Baccalaureate Social Work, 5(2): 113-126.

Steadman, M.H. (Ed.). (1998). Using classroom assessment to change both teaching and learning [Special issue]. New Directions for Teaching and Learning, 75.

Stein, J. (2003). Attitudes of social work students about substance abuse: Can a brief educational program make a difference? Journal of Social Work Practice in theAddictions, 3(1) 77-90.

Steiner, S., Stromwall, L., Brzuzy, S., \& Gerdes, K. (1999) Using cooperative learning strategies in social work education. Journal of Social Work Education, 35(2), 253-264. 
Stocks, J.T., \& Freddolino, P. (1998) Evaluation of a world wide web-based graduate social work research methods course. Computers in Human Services, 15(2-3) 51-69.

Stoltenberg, C.D., \& Delworth, U. (1987) Supervising counselors and therapists: A developmental approach. San Francisco: Jossey-Bass.

Sue, D., Arredondo, P., \& McDavis, R. (1992). Multicultural counseling competencies and standards: A call to the profession. Journal of Counseling and Development, 70, 477-486.

Taylor, I. (1999). Portfolios for learning and assessment: Laying the foundations for continuing professional development. Social Work Education, v.18(2):147-160.

Thyer, B. (2002). How to write up a social work outcome study for publication. Journal of Social Work Research and Evaluation, 3(2): 215-224.

Tungate, S., Lazzari, M., \& Buchan, V. (2001). Listening to student voices: An essential element in social work education assessment. The Journal of Baccalaureate Social Work, 6(2): 97-114.

Urbanowski, M.L. (1988). Learning through field instruction: A guide for teachers and students. Milwaukee, WI : Family Service of America.

VanLeit, B. (1995). Using the case method to develop clinical reasoning skills in Problem Based Learning. TheAmerican Journal of Occupational Therapy, 9, 349-353.

Visvesvaran, P. (2000). Admission criteria and internal assessment in a school of social work: An analysis. The Indian Journal of Social Work, 61(2): 255-268.

Vourlekis, B., Bembry, J., Hall, G., \& Rosenblum, P. (1996). Testing the reliability and validity of an interviewing skills evaluation tool for use in practicum. Research on Social Work Practice, 6(4), 492-503.

Vourlekis, B., Bembry, J., Hall, G., \& Rosenblum, P. (1992). Evaluating the interrater reliability of process recordings. Research on Social Work Practice, 2(2), 198-206.

Vye, N.J., Schwartz, D.L., Bransford, J.D., Barron, B.J., Zech, L., \& Cognition and Technology Group at Vanderbilt. (1998). SMART environments that support monitoring, reflection, and revision. In D. Hacker, J. Dunlosky \& A. Graessner, (Eds.), Metacognition in educational theory and practice. Mahwah, N.J.: Erlbaum.

Waites, C. (2000). Assessing generalist problem solving skills: An outcome measure. The Journal of Baccalaureate Social Work, 6(1): 67-79.

Walvoord, B., \& Anderson, V. (1998). Effective grading: A tool for learning and assessment. San Francisco, CA: Jossey-Bass.

Weaver, H.N. (1998). Teaching cultural competence: Application of experiential learning techniques. Journal of Teaching in Social Work, 17(1/2), 65-79.

Weiser, I. (1994). Revising our practices: How portfolios help teachers learn. In L. Jackson \& R. Caffarella, R., (Eds.), Experiential learning: A new approach, 62(Summer). CA: Jossey Bass. 293-301.

White, E.M. (2000). Bursting the bubble sheet: how to improve evaluations of teaching. The Chronicle of Higher Education, 47(11):B11. (November 10, 2000).

Winans, D. (2003). Proving their worth. NEA Today, v.22(2):36.

Wolfer, T., \& Johnson, M. (2003). Re evaluating student evaluation of teaching: The teaching evaluation form. Journal of Social Work Education, 39(1): 111-121.

Yancey, K.B., \& Weiser, I. (1997). Situating portfolios: Four perspectives. Logan, Utah: Utah State University Press.

Younes, M.N. (1998). The gatekeeping dilemma in undergraduate social work programs: Collision of ideal and reality. International Social Work, 41(2), 145-153.

\section{Author's Note:}

Address correspondence to: Robert Vernon, Indiana University School of Social Work, 902 West New York Street, Indianapolis, IN 46202-5156, USA. E-mail: vernon@iupui.edu 